\title{
Bir Hayatı Çağdaş Bir Sergi Formuna Dönüş̧ürmek: Harald Szeemann'ın Saplantılar Müzesi
}

Prof. Necla RÜZGAR

Hacettepe Üniversitesi

GSF, Resim Bölümü

neclaruzgar@gmail.com

ORCID: 0000-0003-2560-5332

\begin{abstract}
Öz
Harald Szeemann, 1974'te Bern'deki apartman dairesinde, mesleği kuaförlük olan büyükbabasına ait çeşitli nesnelerden oluşan bir koleksiyonu sergilemiştir. Sergi, "Saplantılar Müzesi" ya da alt başlı̆ıyla "Büyükbaba: Bizim Gibi Bir Öncü" adını taşımaktadır. Bu bir hayałı bir sergi olarak göstermeyi amaçlayan öncü bir girişimdir. "Büyükbaba: Bizim Gibi Bir Öncü" sergisinde Szeemann, başarılı bir kuaför, peruk yapımcısı ve kendi perma makinasını icat eden Macar göçmen büyükbabası Étienne Szeemann'ın hayatına odaklanmaktadır. "Kişiseletnografi" olarak okunabilecek bu sergi ile Szeemann, kendi aile üyelerini incelemiştir. Bu sergi aracılığı ile Szeemann, bu aileye ait sıradan ve gündelik nesneleri bir sanat eseri olarak sunmuş, bu nesnelerden oluşan bir çağdaş sanat müzesi önermiştir. "Saplantılar Müzesi", hem bir düşünce havuzu ve hem de Szeemann'ın tüm sergilerini içeren bir depo niteliği taşımaktadır. Szeemann, bu projesi ile izleyicilere, kapitalizm ve sosyalizm politikaları, eşzamanlı olarak, ekonomik, sınıfsal ve ötekilik politikalarını işaret eden kültürel olarak saldırgan bir sosyal eleştiri sunmaktadır. Bu araştırmanın amacl; günümüz sanatında sıklıkla kullanılan sergileme tekniklerinin yaratıcılarından olan Harald Szeemann'ın, 1970'lerde uyguladığı sergileme modelini inceleyerek sanat tarihsel referansları görünür kılmaktır.
\end{abstract}

Anahtar Kelimeler: sergi, sergi modelleri, Harald Szeemann, saplantılar müzesi, büyükbaba: bizim gibi bir öncü.

Rüzgar, N. (2021). Bir Hayałı Çağdaş Bir Sergi Formuna Dönüştürmek: Harald Szeemann'ın Saplantılar Müzesi. ARTS: Artuklu Sanat ve Beşeri Bilimler Dergisi, 5, ss. 10-22. 


\title{
$\operatorname{arts}=$
}

Research Article

\section{Transforming a Life into a Contemporary Exhibition Form: Harald Szeemann's Museum of Obsessions}

\begin{abstract}
In 1974, Harald Szeemann exhibits a collection of various objects belonging to his grandfather, who is a hairdresser. The exhibition is called "The Museum of Obsessions" or with subhead "Grandfather: A Pioneer Like Us". This is a pioneering attempt to show a life as an exhibition. In the exhibition "Grandfather: A Pioneer Like Us", Szeemann focuses on the life of Étienne Szeemann, a successful hairdresser, wig maker and Hungarian immigrant grandfather who invented his own perm machine. With this exhibition, which can be read as "personalethnographic", Szeemann examines his own family members. On the occasion of this exhibition, Szeemann presented ordinary and everyday objects belonging to this family as a work of art and proposed a contemporary art museum consisting of these objects. He presented a culturally aggressive social critique to the viewers, which simultaneously pointed to the politics of economic, class and otherness, and the policies of capitalism and socialism. The "Museum of Obsessions" is a pool of thought and a repository containing all of Szeemann's exhibits. The purpose of this research; to make art historical references visible by examining the exhibition model applied by Harald Szeemann, one of the creators of the exhibition techniques frequently used in today's art, in the 1970s.
\end{abstract}

Keywords: exhibition, exhibition models, Harald Szeemann, museum of obsessions, grandfather: a pioneer like us. 


\section{arts}

\section{GíRiş}

1933 yllında Bern'de doğan Harald Szeemann (1933-2005), 20. yüzylın ikinci yarıııın en önemli sergi küratörlerinden birisi olarak kabul edilmektedir. 1961'de başına geçtiği Kunsthalle Bern'de büyük yankı uyandıran çağdaş sanat sergileri düzenleyerek buranın tüm dünyada tanınmasını sağlayan Szeemann, 1969'daki "Tutumlar Biçime Dönüşünce / When Attitudes Become Form" sergisiyle bir dönüm noktası yarattığı söylenebilir. Çok sayıda genç sanatçı, bizzat serginin içinde ortak bir atölye fikrini deneyimlemiş ve 'sanat kavramının genişletilmesi' üzerinde çalışmıştır. Bu sergi Szeemann'ın 1972' deki Documenta 5'in yönetimine gelmesini sağlamış̧ır. Harald Szeemann ilk profesyonel küratör olarak kabul edilmektedir, 20. yüzyllın ikinci yarıında Szeemann'ı izleyenlerin, onun ansiklopedik bir yaklaşımla değil, şaşırtıcı bir anlayışla düzenlediği sergileri deneyimledikleri söylenebilir. Sanat için yeni bağlamlar tanımladığı ve çağdaş sanatı ve küratöryal uygulamaları derinden etkileyen yeni sesler ve yaklaşımlar sunduğu ifade edilebilir. Sanat dünyasına yepyeni bir soluk veren sergilerden biri de bu metinde ele alınarak incelenmiş olan "Saplantılar Müzesi / Museum der Obsessionen" ya da alt başlı̆̆ı "Büyükbaba: Bizim Gibi Bir Öncü / Großvater - Ein Pionier Wie Wir" olan sergidir (Görsel 1). 1974' de mesleği kuaförlük olan büyükbabası üzerine açıı̆ı bu sergide, büyükbabasının mülkünü bir yerleştirme (enstalasyon) olarak sunmuştur. Bu projenin yaşanıımış bir hayatı bir sergi olarak yeniden inşa ederek izleyiciye sunmak üzere yapılan öncü bir girişim niteliği taşıdığı söylenebilir.

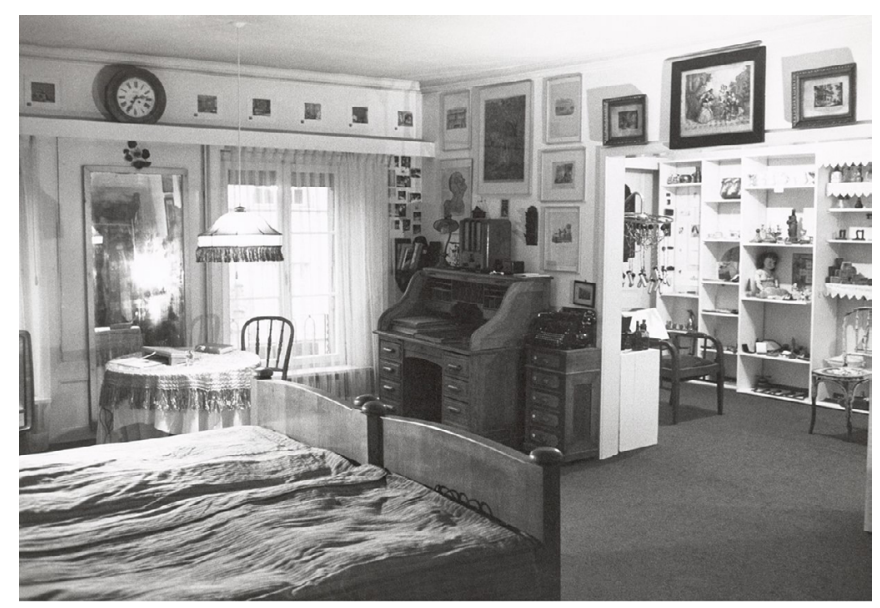

Görsel 1. Harald Szeemann, 1974, Saplantılar Müzesi (Museum der Obsessionen), sergi görüntüsü. Artmap. goo.gl/akQo8S 


\section{Kurgusal Müze}

"Saplantılar Müzesi" adını taşıyan bu özerk 'kurum' günümüzde yeterince bilinmiyor olsa da, bu hayali müzenin Szeemann'ın en büyük girişimi ya da gayreti olarak ifade edilebilir. Doris Chon'un (2016, s. 82) ifadesiyle "Saplantılar Müzesi", hem bir düşünce havuzu, hem de Szeemann'ın tüm sergilerini içeren bir depo olarak nitelendirilebilir. Szeemann'ın, "Saplantılar Müzesi", kendi sezgisel takıntılarının bir ürünü olarak ve sanatsal pratikleri kavramasına adanmış 'kafanın içindeki kurgusal müze'dir (Görsel 2).

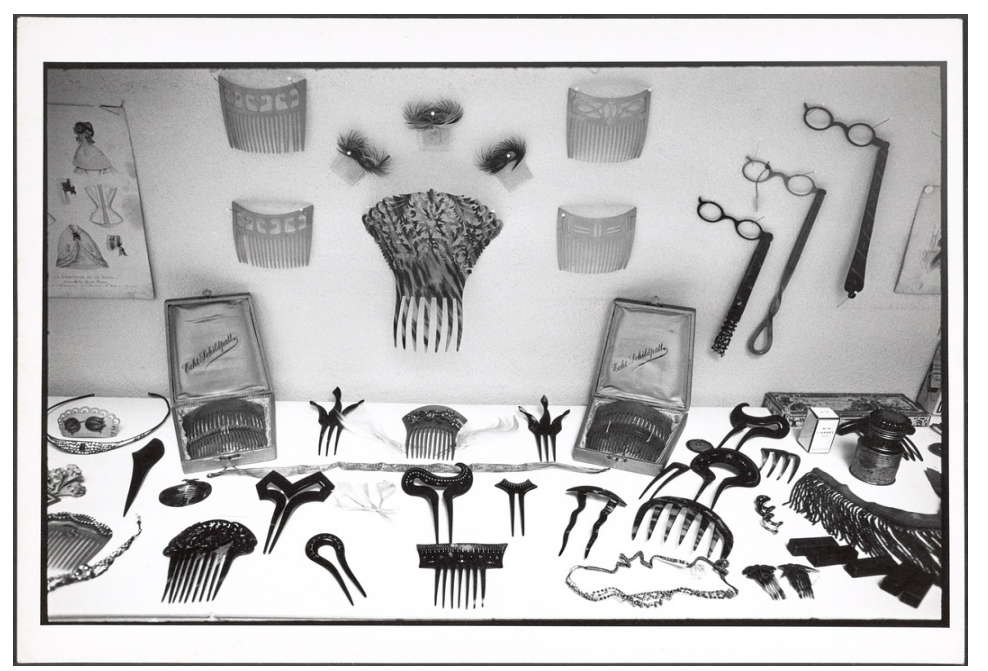

Görsel 2. Harald Szeemann, 1974, Saplantılar Müzesi (Museum der Obsessionen), sergi görüntüsü. goo.gl/tCfG6h

Szemann'ın Documenta 5'de, küratöryal bir öneri olarak ortaya attığı 'bireysel mitolojiler' kavramı kişisel saplantılardan oluşan bu sergiyle devam etmiştir. Bu müze, bir kurum olarak müzenin ve sanatsal pratiklerin geleneksel tanımını çarpıcı bir biçimde genişlettiği kadar, bağımsız bir sergi yapımcısı olarak Szeemann'ın eğilimlerinin ve metodolojisinin kurgusunu da gösterir nitelikte olduğu ifade edilebilir. Szeemann'ın bilgi toplama konusundaki takıntılı yaklaşımı, nefes alan ve yaşayan bir arşiv fikrini yeniden tanımlamak ve doğru şekilde ifade etmek için bir olanağa dönüşmektedir. Sergi Szeemann'ın, büyükbabasına olduğu kadar, sanatsal değerler geleneğine, küratörlüğün temsiline, kürate etme tarafsıllığını sorgulamaya ve güzellik ile sanat arasındaki ilişkiye saygılarını sunması olarak okunabilir.

225.000 ziyaretçisi ve eğer gerekli özen gösterilmezse kolayca kırılacak parçalarıyla Documenta'nın acımasız bir sergi olduğunu vurgulayan Szeemann, 


\section{$\operatorname{arts}=$}

tam da bu acımasızlıkla baş etmek için "Büyükbaba" adını taşıyan, bu küçük ve samimi sergiyi düzenlediğini ifade etmektedir. Szeemann, alaycı bir şekilde bu sergiyi Documenta'yla kıyaslayarak, "dünyanın en büyük sergisinden sonra dünyanın en küçük sergisi" olarak nitelendirmektedir (Szeemann, 1981, s. 40), (Görsel 3).

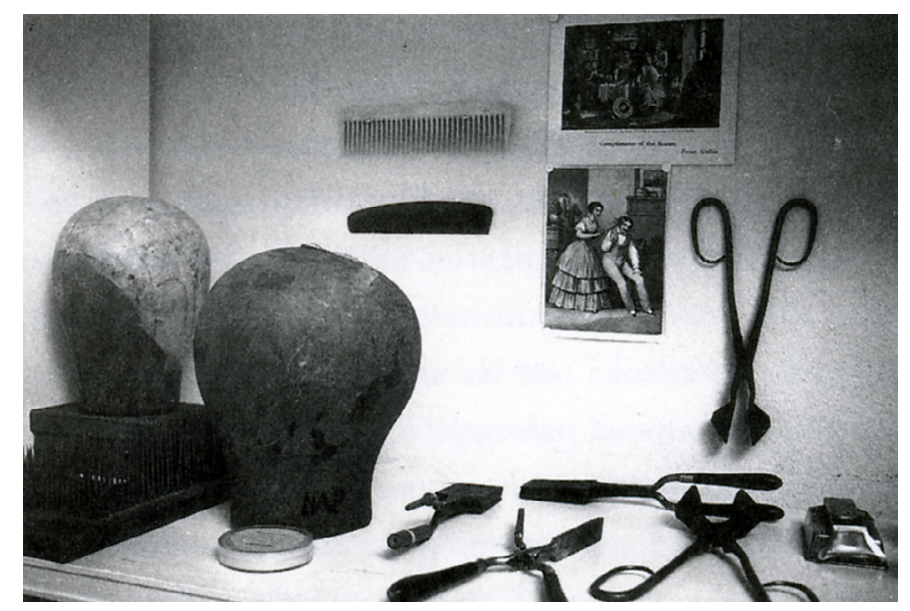

Görsel 3. Harald Szeemann, 1974, Saplantılar Müzesi (Museum der Obsessionen), sergi görüntüsü. Expositions Modernes. goo.gl/WxWSbe

\section{Eve Müze Yerleştirmek}

Saplantılar Müzesi, Café du Commerce restoranının üzerindeki Gerechtigkeitsgasse 74'deki büyükbabanın dairesinde açılış̧ır. Büyükbabanın ölümünden sonra bu daireyi Toni Gerber Galerisi satın aldığı için, bir asırlık hayatı gösteren bu sergi Toni Gerber Galerisinin tarihçesine dahil olmuştur. Szeemann, kataloğun giriş yazısında sergiye dair şu ifadeleri kullanmıştır:

Büyükbaba, ölümünden uzun süre sonra, hakkında konuşulanlarla ve onun yeniden anlatılan hikayeleriyle var olacak. Bu sadece bir sergi. O hayatını hikayelerle aktardı ve hatta onları anılarında korudu. Ben her şeyi buraya aldım. Örneğin yılan yağı ne işe yarar, bir hükümdara nasıl peruk giydirilir, taş gibi bir kurabiye tren camından nasıl fırlatııı, meslektaşlarımızı kıskandığımızda ne yapmalıyı, etik nedir...? (Szeemann, 1981, s. 10).

"Objeleri göstererek bir hayatın nasıl temsil edileceği problemi beni her zaman büyülemiştir" diyen Szeemann (1981, s. 45), Saplantılar Müzesi'ni planlarken, bir evin birebir yeniden inşa edilmesinin burada yeterli olmayacağını fark eder. Bu nedenle sergiye rehberlik edecek bir düzenleme kurgulayarak büyükbabanın kendi düzenini göstermeye girişmiştir. Sergi şu alt başlıklarla sunulacaktır: Soy Ağacl, Büyükanne, Avusturya-Macaristan Kökleri, Bern ve İsviçre, Meslek (acemilik süreci ve 
öğrenme, kendi işini kurma, basılı materyaller ve ayrıntılar), Büyükannenin Mülkleri, Büyükbabanın Parayla İlişkisi, Büyükbabanın Rol Modelleri, Büyükbabanın Güzelliğin Zaferine Katkıları ve Diğerlerinin Söyledikleri (Görsel 4).

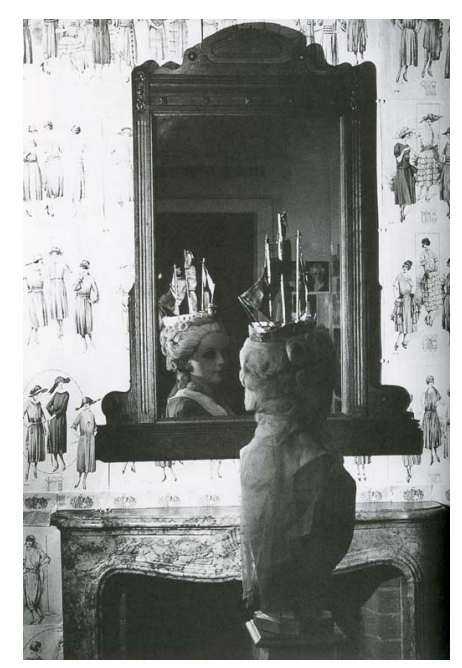

Görsel 4. Harald Szeemann, 1974, Saplantılar Müzesi (Museum der Obsessionen), sergi görüntüsü. Expositions Modernes. goo.gl/JvZtE 1

Szupinska'nın belirttiği gibi; (2010, s. 33-37) büyükbaba Etienne, garipliklerinin tümü ve demode oluşuyla kısmen eski bir kuşağın hepsini, bir İsviçreli veya Avrupalı olmayı temsil ettiği düşünülebilir. Büyükbaba Etienne'in ilginç bir hayatı olmuştur. 1873 yılında Macaristan'ın küçük kasabası Diosd'da doğan ve ıstvan adı verilen büyükbaba, İsviçre'ye yerleştikten sonra adını Etienne olarak değiştirmiştir. 1880-1915 tarihleri arasında yaşanan büyük göç dalgasıyla, büyükbaba da Macaristan'dan ayrımış, yoksulluk ve açlık içinde Romanya, Yunanistan ve Türkiye'den geçerek Viyana, Paris, Londra gibi Batı Avrupa şehirleri arasında dolaşmışłı. Londra'da çok az parayla ne yapacağını bilemez haldeyken, İsviçreli bir kadının ıstvan' a yatacak yer vermesi ve onun da bu iyiliğe karşılık kadının saçlarını yapması gelecekteki yaşantısını şekillendirir. İsviçreli bu aileye duyduğu sempati, onun İsviçre'ye yerleşmesine ve bir kuaför olmasına vesile olur.

Sergi başlığında da vurgulandığı üzere, O bir "öncü"dür: İşci sınıfından bir Macar göçmen, başka bir ülkede küçük bir işadamına dönüşmüş ve ailesi için bir gelecek inşa etmiştir. Onun hikayesi bir Batı başarısıdır! Büyükbaba 89 yaşındayken anılarını yazar. Harald Szeemann da bu anıları Spiegel'e göndermesini önerir. 


\section{arts}

Fakat bu anılar büyükbabanın 95 yaşına kadar yayınlanmaz. Ancak bu zamandan sonra, anılar, Der Schweitzer Spiegel'de "Usta Kuaför Güncesi" başlığıyla yayımlanır. Macaristan doğumlu bu vatandaş, nasıl yaşadığını yazmıştır. Ona göre önemli noktalar önemlidir, diğer her şey ehemmiyetsizdir.

"Büyükbabanın otobiyografisinde, büyük maceralar yokłu" diyen Szeemann (2010, s. 26) büyükbabanın, genel olarak kendini bir kuaför ustası olarak nasıl yetiştirdiğini ve dolu bir hayata nasıl ışık olduğunu aktarır. Tıpkı Napolyon gibi, edepli, büyüleyici, iriyarı ve her şeyden önce inatçı biri olarak dünyayla kendi tarzında savaştığını aktarır. Szeemann'a göre (2010, s. 28), büyükbaba, anahtar deliğinden ünlü saç bigudicisi Marcel'in Viyana gösterilerini gizlice izlemekten, endüstriyel casusluktan geri durmayan, zorlu bir saç sanatçısı olarak engellenemez biriydi. 92 yaşında olmasına rağmen, yaşlı bir adam olarak çok fazla boş zamanı olan büyükbaba, eski ve özel müş̧erilerine hala hizmet veriyordu. Ama o'nun asıl ilgi duyduğu şey torunlarıydı. Dolayısıyla büyükbaba Doktor Harry'nin (bu büyükannesinin Harald Szeemann'ı çağırdığı isimdir) Kunsthalle'de organize ettiği bütün sergilerini ziyaret eder. En iyi Pazar kıyafetini giyen, kadınların ellerini öpen bir açılış kokteyli duayenidir.

Büyükbaba bir kuafördür ve o'nun hayatı sanatın bu türüne adamıştır. Fakat o aynı zamanda çok tutkulu bir koleksiyonerdir. Szeemann'ın sergilediği belgelerden de görüldüğü üzere, büyükbaba yaptığı ödemelerin faturalarını, piyade kartlarını, rozetleri, pulları, iş dokümanlarını ve daha pek çok şeyi biriktirmiştir... Evi, bu nesnelerle dolup taşarken önce üç, sonra iki odaya düşmüştür. Szeemann (2010, s. 27), "1971 'de o'nun ölümünden sonra, evi temizlerken, bana büyükbabamlardan kalan her şeyi aldım" diye yazmakta ve ifadelerine şu şekilde devam etmektedir: "Yıllarca, bir tarihin görselleştirilmesi, bir yaşam tarzının tanıklığı, her bir adamın hayatının genel bir örneği olarak bu evi sergilemeye değer gördüm. Her şeyin apaçık bir işarete döndüğü ve bu biriken işaretlerin artık engellenemez olduğu bir noktaya gelmiştim".

Szupinska (2010, s. 41), bu küçük serginin parametreleri içinde kendi aile üyelerini inceleyen Szeemann'ın, izleyicilere, bir kuaför ve bir küratör, kapitalizm ve sosyalizm politikaları ve aynı zamanda Macaristan ve İsviçre kültürleri arasındaki ucu açık gerçeklikleri göstermeye çalıştığını ifade etmektedir. Küçük bir serginin 
parametrelerinde yer alan bu "kişisel-etnografi" ile Szeemann; kısa, öz ve eşzamanlı olarak, ekonomik, sınıfsal ve ötekilik politikalarını işaret eden, kültürel olarak saldırgan bir sosyal eleştiri sunmuştur. Bałı Avrupa kapitalizmi, Sovyet Sosyalizmi ve İsviçre'nin göçmen işçilere tutumu arasındaki eş zamanlıık ve sergi başlığının izleyiciler üzerindeki etkisi düşünüldüğünde, Etienne Szeemann'ın özel ve yerel öyküsü, o zamanın karmaşık Avrupa gerçekliğine işaret etmektedir. Öyleyse belki de küratörün bu sergiyi kurgulamadaki rolü, sanatçı-küratörlük olarak değil de, etnograf-küratörlük olarak isimlendirilebilir (Görsel 5).

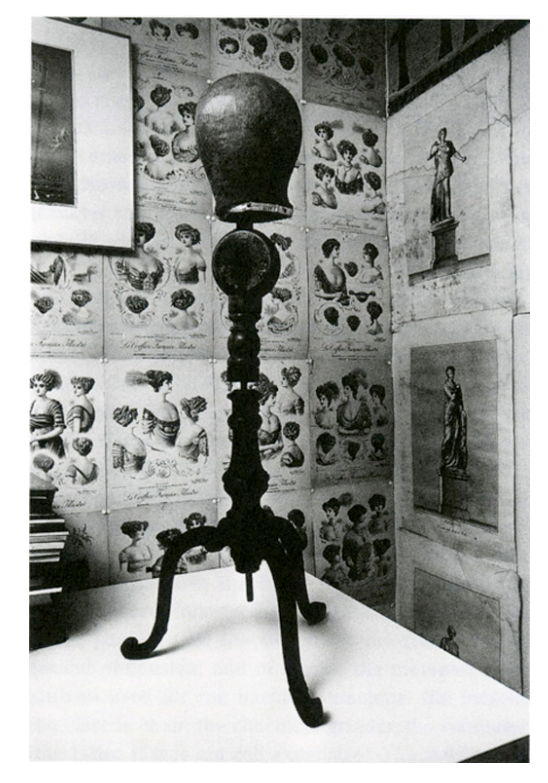

Görsel 5. Harald Szeemann, 1974, Saplantılar Müzesi (Museum der Obsessionen), sergi görüntüsü. Expositions Modernes. goo.gl/iB5TiL

Üstünde durulması gereken bir diğer nokła da sergi başlığında 'bizim gibi bir öncü' denirken ne kastedildiğidir. Buradaki 'biz' kimdir? 'Biz' zamiri, eğer bir kuşağı tanımlamakta ise, özel bir çevreye/gruba atıfta bulunulduğu düşünülebilir. Terim belki de bohem sanatçılardan aristokrat kadınlara ve sergiye iştirak eden diğer herkesi kapsamaktadır. Gerçekten de burada kullanılan 'biz' zamiri oldukça muğlak bir anlam içermektedir. Çünkü kelime kimin konuştuğuna göre yön değiştirebilir ve çok farklı anlamlara kayabilir. Öyle görünüyor ki Szeemann bu kayganlıktan yararlanmak istemiş; belki 'biz' dar anlamıyla 1930'larda doğan kendi kuşağını işaret ediyordu veya kültür üreticilerini, sanatçıları ve sergi yapımcılarını ya da belki serginin yapıldığı şehir olan 1970'lerin Bern'indeki postmodern topluluğu kastediyordu. Sonuçta 'biz', 
muhtemelen ailevi ve ulusal sınıfandırmaların ötesine bakan yeni entelektüeller sınıfını betimleyen bir ifade şeklinde yorumlanabilir.

Szupinska' ’ın (2010, s. 41) vurguladığı gibi küratörün sergi açılışına davet ettiği misafirlerin seçimindeki niyeti de okunmalıdır. Büyükbabanın varlıklı zengin müşterileri ve aynı zamanda çağdaş sanatçılar açılış gecesi apartmanı doldurmuştur. Bu geceyi anımsadığında Szeemann şunları yazmıştır: "Sadece dedemin saçlarını yaptığı kadınlar değil; Sigmar Polke, Michael Buthe, Katharina Sieverding, Christian Boltanski, Mario\&Marisa Merz, Udo Kier ve diğer birçok sanatçı da katıldı. Büyükbabamın mobilyalarında neredeyse sefahat dolu bir geceydi." (Görsel 6,7).

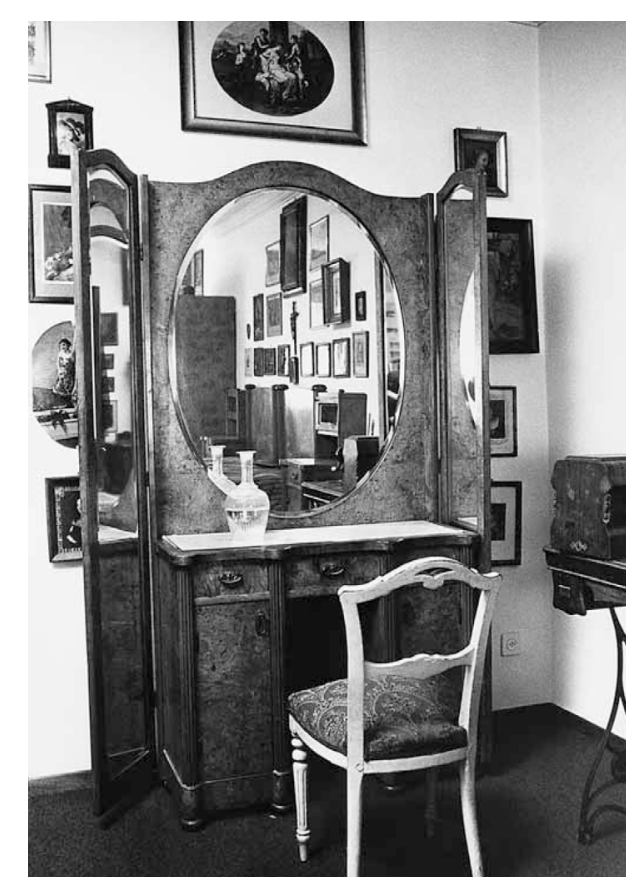

Görsel 6. Harald Szeemann, 1974, Saplantılar Müzesi (Museum der Obsessionen), sergi görüntüsü. Expositions Modernes. goo.gl/xMD9Vz

Açılışı bir pagan hoşgörüsü hissiyle hatırlamak, Szeemann'ın, sosyal sınıfların karışmasına dair vurguladığı bir tabuyu ortaya koyar nitelikte değerlendirilebilir. Artık hayatta olmayan dedelerinin kuşağı ile 1970'lerin bu farklı kitlelerini bir araya getirerek, Szeemann, en azından kendi akranları için, sınıf ve ulusal hiyerarşinin bittiğini ilan etmiştir sanki. 


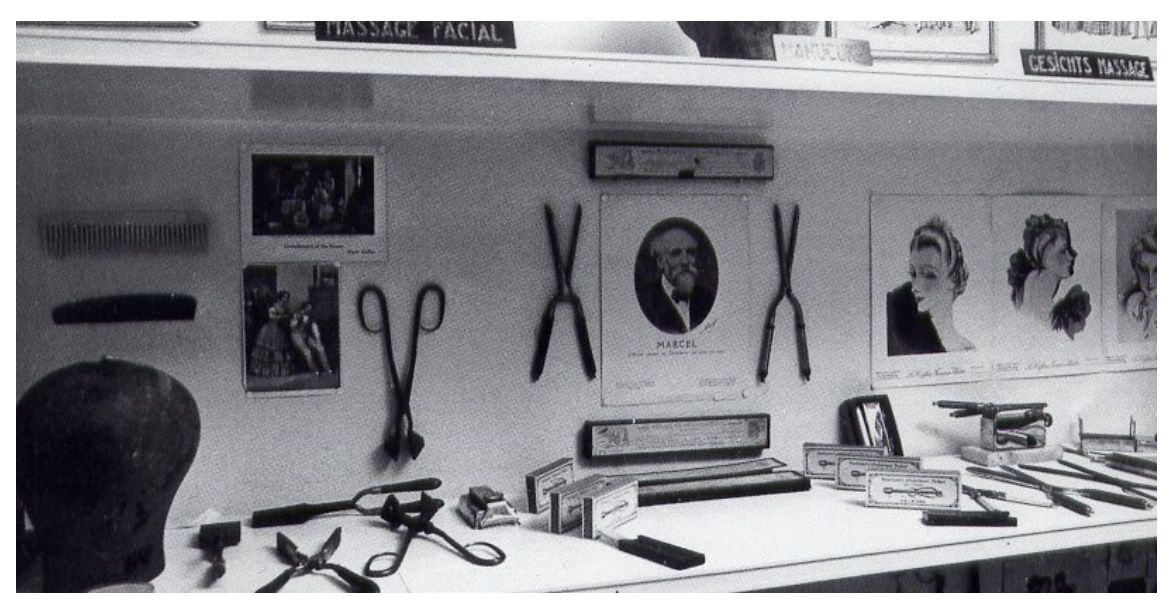

Görsel 7. Harald Szeemann, 1974, Saplantılar Müzesi (Museum der Obsessionen), sergi görüntüsü. Diametre. goo.gl/3zKQ9u

Sanat dünyasında akranları tarafından kabul gören Harald Szeemann, Bern aristokrasisi tarafından ayrımcılığa uğramıştır. Sergi kataloğunun giriş yazısında şu ifadeler yer almaktadır: Yaşlı bir aristokrat kadın Szeemann' a "Büyükbabanız ne iş yapardı?" diye sormaktadır. Szeemann: "Ama siz onu tanıyorsunuz. O bir kuafördü" cevabını verir. "Peki ya babanız?" diye sormaya devam eden kadına, Szeemann: "Babam da aynı, o da bir kuafördü" diyerek karşılık verir. Bunun üzerine kadın: "Ve sen bir müze yöneticisisin! Ne başıbozukluk!" ifadesiyle tepkisini gösterir (Szeemann, 1981, s. 20).

Yukarıda yer verilen diyalogdan; kadının sınıfların karışmasına duyduğu nefreti dile getirdiğini ve bir aristokrat olarak, soylulara karşı açıkça skandal bir başkaldırı olarak gördükleri bu karşılaşmayı eleştirdiği sonucuna varabiliriz. Çünkü aristokratları bu sergi davetedenSzeemann'ın, sınıflar arasındaki ayrımı kuvvetlendirme çabasında olduğunu, şok edici bir taktik uyguladığını ve farklı sosyo-ekonomik yapılara sahip olan insan gruplarını bir araya getirerek o zamanlarda çoğunlukla görmezden gelinen politik bir noktayı görünür kıldığını söylemek mümkündür. Szupinska'nın (2010, s. 38) ifade ettiği üzere; köklü gelenekleriyle gurur duyan aristokrat kadınlar ve yenilikçi sanatçılar sergiye davet edilmişler ve serginin bir sahnesi, bir elemanı olarak aynı mobilyalarda oturtulmuşlardır. Oda bu karakterle doluncaya kadar, sergide yer alan nesneler muhtelif anlamlarına kavuşamazlardı.

Obrist'in (1996: 77) aktardığına göre, ilerleyen dönemde; Szeemann'ın müze 


\section{arts}

yöneticiliği görevini bırakması, sanat dünyasında genellikle onun kendi kararıymış gibi bilinmektedir. Oysa onun, yaratıcılık için bağımsızlık istemesi sadece sergi salonunun bürokrasisinden kurtulmak arzusundan kaynaklanmamaktadır. Başka politik nedenler de vardır. Yıllar sonra bu süreçten bahsederken, o yıllarda, yabancı işçilere karşı bir düşmanlığın kendini göstermeye başladığını, İsviçre' deki yabancıların sayısını azaltmak için bir siyasi parti kurulduğunu ve kendi ismi İsviçre asıllı değil de Macar olduğu için saldırıya uğradığını yazmaktadır. Bu duruma cevap olarak, İsviçre'deki İtalyan, Türk ve İspanyol işçilere "misafir işçiler" denildiği için politik bir beyanat olarak "Ruhsal Misafir İşler Acentası"nı kurduğunu belirtir.

\section{SONUÇ}

Yüksek sanat ve dışlanmış sanat arasındaki engeli ortadan kaldırmayı arzulayan "Saplantılar Müzesi", eşzamanlı olarak Ortaçağ'dan Jung'a kadar olumsuz çağrışımlar yapan "saplantı" kelimesini de merkeze almış ve "saplantı" kavramını bireyleşme süreci açısından olumlu bir enerji türüne dönüştürmüştü. Kuşkusuz ki Szeemann'ın "saplantı" parolası, dünyanın kıyısında kalanlarla, Batı'nın sanat kahramanlarına, Art Brüt sanatçılarından usta sanatçılara kadar herkesi içine alıyordu. Bu kavram, elbette ki Szeemann'ın küratörlük tutumunu da özetliyordu. "La Fabbrica Rosa / Pembe Fabrika" olarak bilinen İsviçre'deki geniş bürosu, harikulade zengin mektuplar, kitaplar, hediyeler, sanat eserleri, hatıra dosyaları, yaklaşık 25.000 sanatçının dosyası ve farklı türden ve farklı formatlara sahip bir çok nesneyle dolu bir arşiv niteliği taşımaktadır.

Hans Ulrich Obrist (2005, s. 25), Szeemann anlayışına dikkat çekerek, o'nun kendi sergilerini "dönüşümlü bir arşiv" olarak gördüğünü ifade etmektedir. Ve Obrist, buna ek olarak, Szeemann'ın kariyerinin bir diğer önemli özelliğinin de, büyük ve küçük, özel ve halk arasındaki salınımı olduğuna işaret ederken; örneğin 1972'de Kassel'deki Documenta'dan sonra, Bern'deki evde büyükbabasına adadığı bu sergiyi kurmasının, onun sergiler arasında bir hiyerarşi gözetmemesinin bir göstergesi olduğuna dikkat çekmektedir. 


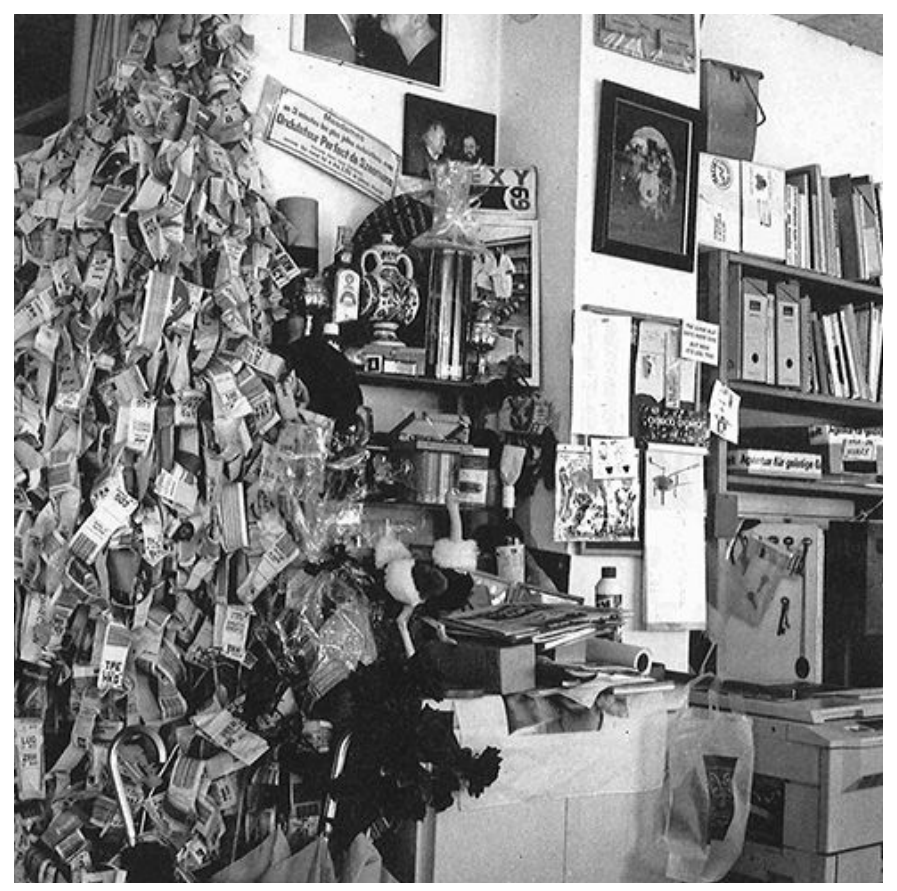

Görsel 8. Harald Szeemann, 1974, Saplantılar Müzesi (Museum der Obsessionen), sergi görüntüsü. Divus. goo.gl/BboF6b

Szeemann'ın, deneysel sergileriyle ve kendine özgü imajı olan ve dünya çapında ün kazanan bir küratör olduğu kabul gören bir gerçekliktir. Onun için söz konusu olanın; daha önce görülmeyen ya da henüz doğru bağlamda görülmeyen şeyleri görselleştirmek olduğu söylenebilir. Bu anlayıştan hareketle geleneği bozan sergiler gerçekleştirmiştir. Gerek bu yaklaşımı, gerekse de sanatçılarla çalışma tarzıyla, küratöryal yaklaşımları değiştirmiş bir küratördür. Szeemann'ın, sergi yapımcıları arasında bir sanatçı olduğu söylenebilir. Yalnızca sanatçıların yanında olması, onları savunması anlamında değil, bir esin kaynağı olarak yaklaşımlarının tümüyle de sanatçılardan biri olmuştur. Sanat tarihinde sıklıkla tanık olduğumuz üzere; Szeemann, çalışmalarını müzecilik camiasına bir alternatif olarak deklare etmişken, onun fikirlerinin ve tekniklerinin günümüzde müzecilik ve müze kültürü tarafından büyük ölçüde benimsendiğini ve kullanıldığını görmekteyiz.

\section{KAYNAKÇA}

Chon, D. (2016). Harald Szeemann's Museum of Obsessions: The Legacy of a Mythological Institution. The Universty of Chicago Press Journals, 8, 82. Erişim: 02 
Ocak 2018. goo.gl/vA49kf

Szeemann, Harald. (1981). Museum der Obsessionen. Berlin: Merve Verlag.

Szeemann, Harald. (2010). HSz: As is/As if. J. Myers \& L. Markopoulos, (Ed). Grandfather: An Exhibition and An Invitation For Subscription. s. 25-30. California: CCA MA Program Publishing.

Szupinska, J. (2010). HSz: As is/As if. J. Myers \& L. Markopoulos (Ed). Grandfather: A History Like Ours. s. 30-42. California. CCA MA Program Publishing,

Obrist, H. U. (1996). Mind Over Matter: Interview With Harald Szeemann. Artforum, 35, 74-79.

Obrist, H. U. (2005). Harald Szeemann 1933-2005. Frieze, 91, 25. 